\title{
Language Politeness for the Knowledge-Based Society 5.0
}

\author{
Sahid Teguh Widodo ${ }^{1, *}$ \\ ${ }^{1}$ University Centre of Excellence Javanology for Javanese Traditions, Universitas Sebelas Maret, Surakarta, \\ Indonesia \\ ${ }^{*}$ Corresponding author. Email: sahidteguhwidodo@yahoo.com
}

\begin{abstract}
Globalization changes the face and posture of culture and influences the language sovereignty of each country that puts forward individualistic values in its new form. The handling of language and culture as the front line and identifiers of a large national cultural framework is recognized to be less than optimal resulting in attitudes chaos, forms, and language deviations. Traditional symbolic patterns change rapidly, resulting in world views changes, traditions, and cultural tastes that are almost without criticism. This phenomenon triggers the emergence of several fundamental problems related to the prospect of language use, is language politeness still needed in the era of Knowledge-Based Society 5.0 (KBS), what are the implications, and what is the solution to this problem? This simple study concludes that language politeness is necessary for the KBS era. There are three basic steps in language development in the KBS era, namely the foundation of spirituality, the basis of universality, and building the civilization. The politeness of the language is still needed regarding manners, attitudes, and control of language stimuli. Further it is given the potential for the destruction of civilization it starts from the language.
\end{abstract}

Keywords: development, language, politeness, sovereignty

\section{INTRODUCTION}

Modernization has developed advance. Digital products have successfully penetrated the nature of time and space [1]. Digital technology is a source of world information, references, medium, and laboratories, a place to meet and interact, and at the same time a battleground for people from various groups and national groups [2]. It's no exaggeration to say that digital technology has usurped humanity's position as a cultural producer.

Globalization has changed the face and posture of culture that affects the language sovereignty of each country. The unique and diverse tastes of ethnic languages and cultures face to face with globalization that generalizes individualistic values in their new forms. Management of culture and language as guardians and characters of a large framework of national culture is recognized less than the maximum. In result, there is confusion in attitudes, forms, distortions of language, confusion, and overlaps culture. On the other hand, scientists and theorists of language, society and culture are less responsive to these very rapid changes. They move in the wallow of the theory of space / "T" / as the basic label of the formation of a deified discipline of science! As if there is no positive productivity space outside the "T". As a result, culture ran far ahead, even faster than imagination.

Since digital devices were promoted, information technology has been developing amazingly [3]. Traditional symbolic patterns change quickly and replaced by sophisticated findings of modern knowledge that are almost passed without criticism. Digital civilization produces a variety of industrial market products that affect cultural tastes, educational systems, forms of society, and the economy that are all new. Improving the quality of life and welfare of life can be a trigger of citizen's awareness about the importance of science and technology in life. This thought sparked the birth of the concept of "Knowledge-Based Society 5.0" (KBS-5.0) as the result of the latest cultural and humanitarian revolution. The schema of the establishment of KBS5.0 can be seen below:

a. KBS can be seen as an illustration of a knowledgebased society to handle the various impacts of science and technology. It determines the language posture and culture of a nation's future.

b. Society and language are two sides in one area of life [4]. 
c. Along with the development of science and technology, language is also experienced a very significant change.

d. The influence of the form changes the meaning. While the function of language produces changes in world views, traditions, and cultural strategies.

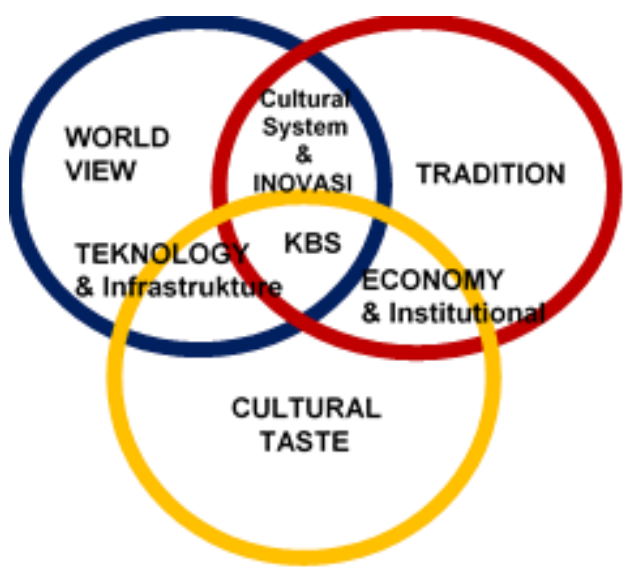

Figure 1 The schema of the establishment
Knowledge-Based Society 5.0 is the development of the structure of macro thinking about information with language as its basic material. Language is a system of sound symbols that results from a human speech which has a natural function and is attached to a unique and diverse context (dependent context). Language grows and develops along with the cultural reality of users, creators, conservationists that directly use language.

In reality, language development is not always linear, causal, or refers to its momentum. Language forms, shaped, and is constructed by various objective, subjective and inter-subjective realities of a time. Naturally, language is called a developer of reason and cooperation [5] on one hand. On the other hands also contains many things that are vague, ambiguous, and often cause misunderstandings. Every decade, culture shows various forms, functions, focus, areas, concerns, and weaknesses. The difference in the unexpected use of language potential is what we call the mindset jump because the results of our search study are as follows, shown in Table 1 .

Table 1. Leap in Language Mindset

\begin{tabular}{|l|l|l|l|}
\hline \multicolumn{1}{|c|}{ LIBERALIZATION } & \multicolumn{1}{c|}{ MODERNIZATION } & \multicolumn{1}{c|}{ KBS } \\
\hline GENERAL FUNCTIONS & $\begin{array}{l}\text { Language discusses something } \\
\text { unfinished }\end{array}$ & $\begin{array}{l}\text { Language conveys ideas and } \\
\text { new creative works }\end{array}$ & $\begin{array}{l}\text { Looking for a Challenge } \\
\text { of language functions }\end{array}$ \\
\hline PRODUCT & Stability \& Incentives & $\begin{array}{l}\text { The use of language in } \\
\text { modern institutions, rules and } \\
\text { laws }\end{array}$ & $\begin{array}{l}\text { Language Vision, } \\
\text { Encouraging birth of a } \\
\text { winning generation, modern } \\
\text { business that is very dynamic }\end{array}$ \\
\hline FOCUS & Economy & Productivity & $\begin{array}{l}\text { Competitive } \\
\text { Global }\end{array}$ \\
\hline AREA & Outside, executor, etc. & Economy, social & Community \\
\hline GOVERMENT & Is liberalization too fast? & Good Lawmaker & Challenger, Integrator \\
\hline WORRIED & Is modernization too slow? & Other nations leave us? \\
\hline
\end{tabular}

\section{MATERIALS AND METHODS}

This research used a multidisciplinary research library model. The form of research is qualitative since it is considered appropriate and able to provide a complete picture [6]. The second reason is based on the characteristics of the research problem, data sources, and research data [7]. The data in this study were collected and analyzed using three-component interactive work methods, namely data reduction, data presentation, and verification [8]. The strategy used in this study is a single case study strategy, namely various phenomena and articles and references on knowledge-based society 5.0. Data collection techniques used Content Analysis and interviews [9]. The data analysis technique is an interactive model data analysis technique that moves between the three components of the analysis which include data reduction, data presentation, verification and concluding.

\section{DISCUSSION}

\subsection{The Language Politeness in the KBS Era}

The assumption that language upholds morality is not without reason. Language is used by all beings in different ways. Humans use language to dialogue with themselves, with their social or collective groups, and with the Most Beautiful, Allah SWT. For himself, humans use language as a means to foster a spirit of "humanity", which is a soul that is delicate and very human, and cultured [10]. 
Quite clearly if it is stated that language encapsulates reality, it guides humans to see, understand, and feel the reality of the universe, more than just the ability of the senses [11]. Language allows people to see things above reality, or even on occasions that are not in accordance with moral rules. This is an exclamation point, why moral analysis of language becomes important to be expressed and understood (Table 2).

Table 2. Changes in Language Symbols and Norms

\begin{tabular}{|c|c|c|}
\hline CATEGORY & SYMBOL-NORM & LANGUAGE POLITENESS \\
\hline Traditional Society & Mythic - Compliance & $\begin{array}{l}\text { 1. The layered language moral system can create order of the cosmos and symbols } \\
\text { of local power. } \\
\text { 2. Politeness language occupies an important position and becomes a socio-cultural } \\
\text { system of the community }\end{array}$ \\
\hline $\begin{array}{l}\text { Capitalist- } \\
\text { technocratic }\end{array}$ & Realist-Individual & $\begin{array}{l}\text { 1. Language is a direct link between speech actors, between the author and the } \\
\text { reader, between the authority and the ordinary people } \\
\text { 2. Simplification of the potential of language to maintain the intensity of interaction } \\
\text { so that ideas, mandates, or moral language can be conveyed and understood. } \\
\text { 3. Moral language becomes a personal responsibility, a personal mirror, being a } \\
\text { "pathos" to the interconnected parties. }\end{array}$ \\
\hline $\begin{array}{l}\text { Digital - Cybernetic } \\
\text { Virtual }\end{array}$ & Soliter-impersonal & $\begin{array}{l}\text { 1. Digital technology has displaced humans as producers of language and culture. } \\
\text { 2. Human language contacts are understood from a series of numbers. The web } \\
\text { page replaces the home address, and the unique community is uniform in the WA, } \\
\text { Tumbler, Twitter, Line, Path, etc. groups. } \\
\text { 3. Each person has derived himself into haunted figures who melt on an infinite social } \\
\text { network site, non-touch, and non-senses. Moral language is increasingly difficult } \\
\text { to define when truth means without proof (post-truth) }\end{array}$ \\
\hline
\end{tabular}

\subsection{The Implications}

1. The language of humanity must be strengthened to overcome the limitations of humans in finding certain mean to continue to have principles, to believe in those principles, and to seek their realization in life that is getting older and vulnerable to death.

2. The language of humanity must be believed to be able to maintain the ability and efficacy of humans to reach "homo humanus", namely human language that has a smooth soul has a sense of humanity, and is cultured

3. Humans cannot be passively waiting for the death of the meaning and function of the language. Good and politeness language must exist in every breath, in every letter, word, and sentence of the language produced from it, as well as everything it thinks about [10].

The language of humanity enables humans to improve themselves. Starting from the language to reduce the other virtues of fellow creatures, nature and the environment, and God's blessings throughout his life.

4. Choice of words, attitude of language pronunciation, and politeness of language that reflects good values must be believed to be able to "soften" the pressures and conflicts

\subsection{The Language of Humanity}

In the early 1960s, Panosky [12] recounted the origin of the term human language. Narrated, near the death of picking up, Imanuel Kant almost lost his golden voice due to damage to the vocal cords due to his age. Before his last breath stopped, he said the pain he was suffering from did not eliminate the sense of humanity in him, even though he could not avoid old age. In line with that, Hugo stated that the death penalty is inevitable, but we do not know when it happened [13]. Within the limitations of this life, it is important for humans to still have principles, beliefs, and seek their realization in lives that are vulnerable to death [14].

1. The language of humanity must be believed to be able to maintain the ability and efficacy of humans to reach "homo humanus", namely human language that has a smooth soul, has a sense of humanity, and is cultured

2. Humans cannot be passively waiting for the death of the meaning and function of the language. Good and politeness language must exist in every breath, in every letter, word, and sentence of the language produced from it, as well as everything it thinks about [10]

3. The language of humanity enables humans to improve themselves. Starting from the language to reduce the other virtues of fellow creatures, nature 
and the environment, and God's blessings throughout his life

4. The choice of words, the attitude of language pronunciation, and politeness of language that reflects good values must be believed to be able to "soften" the pressures and conflicts

The term Humanitarian Language is rarely heard. This term reminds us to the end of the life of Immanuel Kant. In his old age, Kant was seriously ill. His health quickly declined and his voice almost disappeared. In front of his students, Kant said that his humanity did not disappear from him, even though he could not avoid the coming of death. The practice of establishing Kant is actually the essence of the language of humanity. Politeness and flexibility with an intellectual spirit are important and historical foundations. Humans are (once again) limited puzzle creatures. Language has the ability to increase the ability and efficacy of humans to achieve "homo humanus", people who speak human language who have a gentle soul, have a sense of humanity, and are cultured. Human language is a tool that creates virtue.

\subsection{Oto-Criticism of Politeness Language}

As a communication tool, language is also used effectively to convey social criticism and innovation in various media. Language accompanies the process of changing social systems and various things that might occur, such as input, refutation, acceptance, suspicion, innuendo, and blunders as well as other things that are considered "deviant" [15]. On the other hand, language is a way to explore new ideas, assess and improve old ideas, old paradigms, for the purpose of better social change.

In this context, politeness of language tends to be more interested in the style and aesthetics of its form, manner, and delivery than the content of social criticism. This means that even language can express bitterness, suffering, hatred, horror, hunger, illness, and even death. However, the point is not the situation, but other aspects, such as how "he" is conveyed the language attitudes, pressure, and language aesthetics [10]. What if the language is broken? Then certainly the chaos will occur because the delivery of social criticism becomes difficult to understand and to reach the target.

In addition, the use of language in the social media domain today is very prominent. The language of the media "exists" by involving other participants directly involved even in the opposite direction. The impact of speech is felt and corrected directly. This is why it is said, today technology has taken a large part of the role of humans as a source of culture [16]. Is there still a need for politeness in language on social media? The answer is "Yes, that's necessary!" Social media is an internet-based, online media application that gives users unlimited flexibility to participate, share, create any content through blogs (web logs), wikis, social networks, and other virtual worlds. When our people began to develop ideology and web technology, humans simultaneously reduced themselves to virtual figures that were more ideal in "not choosing" information. The seven digit letters on the word "human" turn into dozens of numbers and web addresses that don't know the boundaries, time, and situation. But something that we have to keep in mind is that, these groups of people form communities, and are bound by the laws and regulations that are enacted under ITE Law No. 19 of 2016 which regulates electronic implementation systems, transactions, intellectual property rights, personal protection, sanctions and criminal penalties for all forms of dangerous fraud.

\subsection{Language Catharsis}

The catharsis of language means the process of "cleansing" a language based on reality or the events of its use in the current context. We often see heated debates in television broadcast programs about something [12]. How is language used by figures, leaders, hosts, and participants in the event, so much we get foreign vocabulary in the form of curses, expressions of hatred, reproaches, and other sentences that have the value of mocking and cornering. Does it natural that such shows get a high rating? Logically it is not, but the reality is indeed so. Dark language is preferred over polite language attitudes and behavior [17].

The same thing we encounter in cyberspace. We also often read comments that are very rude, corner, disgusting swear words in blogs, articles, and electronic newspapers. We can read and watch special everyday language demonstrations so that they appear to be disguised as acceptable fairness. Decisively must be answered "no!" catharsis must be done so that we do not imitate, permissive, and passive, silent with various language phenomena because language is actually a mirror of civilization [15].

Catharsis language arises and is encouraged to reject the primitive emotions of the people themselves who begin to feel happy and entertained with all forms of abusive, frightening and disgusting language that clearly contradicts language morality. Language morality must exist in every language use because it is a language lesson. Sometimes it is a challenge for us to face our own primitive emotions as long as they don't go wild. When we witness the cruel and repulsive practices of language that continue to occur, we become interested in practicing them at other 
opportunities in real life. Coarse language training has become our awareness, danger because it will sink into our memories, our deepest feelings, and our subconscious. If that really happens, language damage occurs along with the collapse of civilization. We might avoid, but doesn't language only convey wise things? Probably. However, the stimulation that arises from something that is artificial does not necessarily have a positive impact. The appearance of images, films, and obscene readings turned out to have a real impact on a very negative life. Second, that the influence of stimuli that are not artificial is precisely the secret of the greatness of language. Here we begin to feel the presence of extraordinary language potential. Able to penetrate artificial reality into real reality.

\section{CONCLUSION}

The general conclusions in this paper are:

(i) Language politeness is still needed and must be the basic foundation of language use in human life. Language Politeness must rely on three values of consciousness:

(a) Godliness Awareness

(b) Universal awareness

(c) Civilization Awareness

(ii) Language politeness should touch the awareness, memory, knowledge, and subconscious of people based on knowledge.

(iii) Maintaining the politeness of language can narrow the space that is immoral and increase studies of language so as to be able to control language stimuli that are often left wild in the realm of praxis.

(iv) Language politeness has laws and controls that are binding, reasonable, given the potential for the destruction of civilization starts from the language.

\section{AUTHORS' CONTRIBUTIONS}

Sahid Teguh Widodo writes all from introduction to conclusion

\section{ACKNOWLEDGMENTS}

Acknowledgements and appreciation to University Centre of Excellence Javanologi for Javanese Traditions Universitas Sebelas Maret for funding the publication.

\section{REFERENCES}

[1] R.D. Abrahams, Between the Living and the Dead, FFC 225, Helsinki: Suomalainen Tiedeakatemia, 1980
[2] A. Kadir, Information Technology, Yogyakarta: Terra chi Press, 2012

[3] A. Koestler, The Act of Creation, New York: Dell Publishing, 1974

[4] H. Read, The Meaning of Art, Baltimore: Penguin, 2007

[5] Sudaryanto, Aneka Konsep Kedataan Lingual dalam Linguistik, Yogyakarta: Duta Wacana University Press, 1999

[6] S.B. Merriam, Qualitative research: A guide to design and implementation, San Francisco: John Wiley and Sons, 2009

[7] M. Yusoff, Penyelidikan kualitatif: Pengalaman kerja lapangan kajian, Kuala Lumpur: Penerbit Universiti Malaya, 2004

[8] B.M. Miles, M. Huberman, Analisis Data Kualitatif Buku Sumber Tentang Metode-metode Baru, Jakarta: UIP, 1992

[9] R.K. Yin, Case study research: Design and methods (4th Ed.). Thousand Oaks, CA: Sage, 2009

[10] B. Darma, Moral dalam Sastra, Basis No. 2/XXXI Pebruari, Jakarta, 1982

[11] T. Eagleton, The idea of culture, Massachusetts USA: Blackwell Publisher Ltd, 2000

[12] E. Panofsky, "The Humanistic Dicipline", Liberal Art Reader, ed. Partlo,, R.B. Englewood Cliffs, N.J. Prentice Hall, 1963, P. 351

[13] P. Walter, "The Renaisance", The Norton Anthropology of English Literature, Vol.II, New York: W.W. Norton \& Co, 2004, p, 1641.

[14] H. Adams, (ed.), Critical Theory Since Plato, New York: Harcourt \& Brace, 1971

[15] R. D'Amico, "Karl Popper and the Frankfurt School", Telos, $1990 \quad$ (86), doi:10.3817/1290086033, ISSN 0090-6514, pp. 33-48.

[16] Suwito, Bahasa dan Indentitas Bangsa, Pidato pen gukuhan Guru Besar, Surakarta: Sebelas Maret University Press, 1989

[17] A.H. Wibowo, D. Djatmika, M.N.S. Ali, N.A.M. Salim, B. Mohamad. "The Texture of Indonesian Story Texts in Teen Literature", International Journal of Innovation, Creativity and Change, 2019. 5(2), 1021-1041 